\title{
IMIGRANTES NO BRASIL - DISCURSOS DE ÓDIO E XENOFOBIA NA SOCIEDADE DA INFORMAÇÃO: COMO ATRIBUIR UMA FUNÇÃO SOCIAL À INTERNET?
}

\author{
IMMIGRANTS IN BRAZIL - SPEECHES OF HATE AND XENOPHOBIA IN THE \\ INFORMATION SOCIETY: HOW TO ASSIGN FUNCTION SOCIAL A INTERNET?
}

\author{
${ }^{1}$ Elany Almeida de Souza \\ ${ }^{2}$ Júlia Marques Rebelato
}

\section{RESUMO}

As relações sociais no âmbito da sociedade da informação apresentam rugosidades, onde alguns usuários da rede mundial de computadores desconsideram complexidades e especificidades das relações interpessoais, fazendo da internet um fim em si mesmo ou um meio para a prática de violações de direitos, consistindo em um verdadeiro paradoxo entre a soberania do objeto x a soberania do sujeito. A realidade da mobilidade humana encontra na sociedade da informação também um desafio, transcender fronteiras imaginárias e derrubar muros pré-conceituais, de modo a instigar uma reflexão sobre a função social da internet, bem como a possibilidade de uma sociedade em rede que amplie direitos e não os mitigue. A discussão aqui proposta chama atenção para a grande propagação de discursos de ódio publicados na internet contra os imigrantes no Brasil e os limites da liberdade de expressão. Tendo-se em vista os fenômenos advindos da sociedade da informação, especialmente no que tangem a divulgação de conteúdos violadores de direitos em seu âmbito, é mister que a internet seja ferramenta também promotora de direitos fundamentais. De forma a cumprir esse objetivo, a pesquisa utilizou-se do método monográfico, por meio de pesquisa bibliográfica e documental, valendo-se de casos emblemáticos representativos da estrutura de construção do discurso de ódio em relação aos imigrantes e os fatores que o influenciaram, para ao final verificar que embora haja previsão legal (artigo 20 da Lei 7.716/89) que puna aquele que praticar, induzir ou incitar a discriminação ou preconceito de raça, cor, etnia, religião ou procedência nacional, agravando ainda a pena se o crime for cometido por intermédio dos meios de comunicação como a Internet, o tipo penal em referência não tem sido suficiente para inibir os discursos de ódio na rede mundial de computadores, o que demonstra que na sociedade da informação ainda paira um sentimento de que seu âmbito ocorre à margem do Direito. $\mathrm{O}$ ordenamento jurídico brasileiro ainda caminha a passos lentos diante da velocidade da rede e tem enfrentado dificuldades no que dispõe aos limites da liberdade de expressão e as práticas discriminatórias e xenofóbicas, sugerindo um verdadeiro enfrentamento quanto à função social da internet como forma de coibir e inibir manifestações odiosas.

Palavras-chave: Imigrantes, Discursos de ódio, xenofobia, Sociedade da informação, Função social, Internet

\footnotetext{
${ }^{1}$ Mestranda em Direito pela Universidade Federal de Santa Maria - UFSM, Rio Grande do Sul, (Brasil). Pesquisadora e Membro do Núcleo - CNPq - Pesquisas em Relações Internacionais de Santa Maria. E-mail: elanyalmeidas@gmail.com

${ }^{2}$ Mestranda em Direito pela Universidade Federal de Santa Maria - UFSM, Rio Grande do Sul, (Brasil). E-mail: juliarebelato@hotmail.com
} 


\begin{abstract}
Social relations in the context of the information society have ridges where some users of the World Wide Web disregard complexities and specifics of interpersonal relationships, making the Internet an end in itself or a means to practice rights violations, consisting of one real paradox between the sovereignty of $\mathrm{x}$ sovereignty of the subject object. The reality of human mobility is in the Information Society also a challenge, transcend imaginary boundaries and tear down preconceptual walls in order to instigate a reflection on the social function of the internet as well as the possibility of a networked society that expands rights and not mitigate. The discussion proposed here draws attention to the wide spread of hate speech published on the internet against immigrants in Brazil and the limits of freedom of expression. Keeping in view the phenomena arising from the information society, especially in that concern the disclosure rights violators content in its scope, it is necessary that the internet is also tool promoter of fundamental rights. In order to meet this goal, research was used the monographic method, by means of bibliographic and documentary research, making use of representative emblematic cases of the building structure of hate speech toward immigrants and the factors that influenced him, to the end find that although there is legal provision (Article 20 of Law 7.716 / 89) to punish that to practice, induce or incite discrimination or prejudice based on race, color, ethnicity, religion or national origin, further aggravating the penalty if the crime is committed through media such as the Internet, the criminal type in reference has not been sufficient to inhibit the hate speech on the World Wide Web, which shows that in the information society still hangs a feeling that its scope is Law rise to. The Brazilian legal system is still walking at a slow pace on the network speed and has struggled in its possession to the limits of free speech and discriminatory and xenophobic practices, suggesting a real face on the social role of the internet as a way to restrain and inhibit odious manifestations.
\end{abstract}

Keywords: Immigrants, Hate speech, Xenophobia, Information society, Social function, Internet 


\section{INTRODUÇÃO}

A internet é um palco onde a comunicação entre as pessoas ganhou uma nova dinâmica, resultado dos avanços da tecnologia da informação, caracterizando-se pela velocidade e abrangência, tanto geográfica quanto no alcance e influência na formação da opinião pública. É nesse cenário que as relações interpessoais atuam e refletem suas complexidades, trazendo à tona uma realidade discriminatória e violadora de direitos fundamentais até então não exposta para além dos pequenos círculos sociais, onde a liberdade de expressão tem sido confundida com uma espécie de direito ilimitado de julgar o outro.

Assim, observa-se, ser cada vez mais comum a propagação de discursos de ódio nas redes sociais, tão utilizadas atualmente como meio de expressão individual. A internet e a liberdade de expressão tem sido utilizadas como instrumentos em atos violadores de direitos humanos, o que torna imprescindível um questionamento sobre os limites dessas práticas, que podem estar ferindo não só o direito de quem é alvo desses discursos, como também de todo um grupo social como é o caso das discriminações e atos de xenofobia externalizados e refletidos em verdadeiros discursos de ódio contra os imigrantes no Brasil.

Essa problematização, como dito, espelha comportamentos já existentes antes dos avanços tecnológicos, mas que foram potencializados face a intensidade e proporção que a internet possui em essência, exigindo uma acuidade do Estado, sobretudo no que toca a proteção da dignidade do indivíduo alvo e/ou do grupo social estigmatizado, apontando os limites da liberdade de expressão, onde a internet possa ser também uma ferramenta a serviço da promoção dos direitos humanos e não um ambiente à margem do Direito.

Imperioso que as redes de fluxos informacionais, além de transcederem fronteiras, possam também derrubar muros pré-conceituais e instigar uma reflexão sobre a função social da internet, bem como a possibilidade de uma sociedade em rede que amplie direitos e não os mitigue, possibilitando outras vozes e posicionamentos que não sejam apenas ecos da mídia hegemônica e da lógica do poder estabelecido, seja ele de que ordem for. Objetiva-se com o presente artigo analisar as varíaveis determinantes nesse contexto de intolerância em que a Internet exerce o papel de uma ferramenta perversa e eficaz nas mãos daqueles que incitam a discriminação contra pessoas que comungam de uma característica identitária, em especial no que respeita aos imigrantes no Brasil.

Tem-se como alvo de estudo dessas manisfetações odiosas, em específico no âmbito da sociedade da informação, como por exemplo o Facebook, pois é a rede social mais 
utilizada e difundida no Brasil, inclusive como formadora de opinão, na medida em que é buscada como fonte de informação e entretenimento. A discussão se mostra socialmente relevante, principalmente porque nos últimos anos o Brasil tem sido destino de fluxos migratórios e a complexidade dos reflexos da mobilidade humana exsurgem não só do ponto de vista de quem migra, mas também daqueles que recebem os imigrantes, sendo a internet também um termômetro na identificação de discriminações, preconceitos e discursos de ódio, no âmbito de uma sociedade até então conhecida internacionalmente como receptiva e solidária.

Utilizar-se-á o método monográfico em combinação com o método estruturalista, buscando-se um padrão nas estruturas e identificando-o, através da utilização de casos emblemáticos representativos da estrutura de construção do discurso de ódio em relação aos imigrantes e os fatores que o influenciaram. O procedimento empregado foi a análise bibliográfica e documental, e como técnicas foram utilizados fichamentos, resumos e coletas de notícias de discursos de ódio na internet. Como marco teórico, foram considerados os ensinamentos de Samantha Ribeiro Meyer-Pflug, Scott Lash, Canclini, Pérez Luño, entre outros que enfrentam as variáveis determinantes do tema proposto.

O presente artigo está dividido em quatro partes, primeiramente, abordar-se-á acerca do discurso de ódio, suas origens na sociedade. Por conseguinte, far-se-á abordagem da dinâmica da atual Sociedade da Informação e o paradoxo da soberania do objeto x soberania do sujeito. Na terceira parte, far-se-á a análise de alguns casos emblemáticos de discursos de ódio na internet em relação aos imigrantes no Brasil e quais os elementos semelhantes que compõem essa estrutura, explicitando acerca dos limites da liberdade de expressão, como se dá a regulação acerca da matéria, inclusive com aporte da interculturalidade como contraponto. Por derradeiro, responder-se-á à pergunta fulcral do presente artigo: como a internet pode exercer uma função social face aos discursos de ódio e episódios de xenofobia proferidos contra os imigrantes no Brasil no âmbito da sociedade da informação?

\section{1 - ORIGENS E ANATOMIA DO DISCURSO DE ÓDIO}

A priori, cabe localizar a perspectiva de análise adotada, eis que a difusão de discurso de ódio a ser analisado consiste em discriminação exaurida por meio de manifestação que segrega, onde é estabelecido uma diferenciação hierárquica entre emissor (superior) e receptor (inferior), e a manifestação toma dimensões além do conhecimento de quem a propaga, ${ }^{1}$ na esfera da sociedade da informação, termo adotado por Lash ${ }^{2}$. 
A propagação do discurso de ódio na sociedade da informação deve ser observada não apenas pelo prisma jurídico, mas também deve-se ter um olhar antropológico e inclusive da psicologia, fazendo-se uma análise interdisciplinar. Nesse aspecto, deve-se observar que o ódio não é uma questão da sociedade moderna, mas sim advindo principalmente de influências do Cristianismo, que trouxe o conceito de culpa e punição de condutas que contrariavam os preceitos éticos e morais ${ }^{3}$.

O ódio tem uma raiz cultural com forte influência do ambiente social e cultural que cerca o sujeito ${ }^{4}$. Também demonstra a fonte de satisfação ou frustração. Ou seja, o ódio pode ter sua fonte no medo ou numa experiência negativa ao lidar com grupos, podendo ser identificáveis com o desdobramento de outros sentimentos, combinando ou interagindo com eles, como dor, inveja, ameaça, medo, frustração e a humilhação. ${ }^{5}$

A ciência toma espaço face ao discurso religioso, e o homem, imbuído na dicotomia bom e mau, vem a apresentar-se na segunda Guerra Mundial como o conceito que o mal adquire feições sociais e nos regimes totalitários como instrumento de dominação, discriminação e extermínio, resultando no holocausto ${ }^{6}$.

O ódio pode conduzir à mais completa falta de empatia pela pessoa odiada, revelandose insensível ao sofrimento alheio, como se testemunhou no lançamento das bombas atômicas sobre Hiroshima e Nagasaki, no episódio de 11 de setembro de 2001, contra as torres gêmeas de Nova Iorque, e no atentado de 9 de março de 2004, na estação de trem de Madri.

Não obstante tudo isso, o ódio é um sentimento tão natural e primitivo quanto a sede, o cansaço ou o amor. É uma reação ao sentimento de humilhação, quando prestígio, dignidade ou autoestima são ameaçados. É um modo de resistir às adversidades e sobreviver às ameaças. Em sua hipertrofia patológica, o ódio gera paranoia, masoquismo, apatia e depressão, estados clínicos nos quais a psicanálise encontra inúmeras afinidades eletivas. ${ }^{7}$

1 SILVA, Rosane Leal da; NICHEL, Andressa; MARTINS, Anna Clara Lehmann; BORCHARDT, CarliseKolbe. Discursos de ódio em redes sociais: jurisprudência brasileira. Revista Direito GV, São Paulo, vol. 14, n. 2, p. 445-468, jul-dez 2011.

${ }^{2}$ LASH, Scott. Crítica de la información. 1. ed. Buenos Aires: Amorrotu, 2005, p. 22.

3 BIRMAN, Joel. Cadernos sobre o mal: agressividade, violência e crueldade. Rio de Janeiro: Civilização Brasileira, 2009. p.21.

${ }^{4}$ STEFFEN, César. Ódio.org.br. In: III Mostra de Pesquisa da Pós-Graduação PUCRS,2008, Porto Alegre. Programa de Pós-Graduação em Comunicação, FAMECOS PUCRS.

${ }^{5}$ GOÉS, Joaci. Anatomia do Ódio. Rio de Janeiro: Topbooks, 2004. p. 274-297.

${ }^{6}$ ARENDT, Hannah. Origens do Totalitarismo: antissemitismo, imperialismo e totalitarismo. São Paulo: Companhia de Bolso. 2012. p. 25

André Glucksmann em Discurso do Ódio afirma 
o ódio existe, todos nós já nos deparamos com ele, tanto na escala microscópica dos indivíduos como no cerne de coletividades gigantescas. A paixão por agredir e aniquilar não se deixa iludir pelas magias da palavra. As razões atribuídas ao ódio nada mais são do que circunstâncias favoráveis, simples ocasiões, raramente ausentes, de liberar a vontade de simplesmente destruir ${ }^{8}$.

Entre as diversas funções do ódio, deve-se avaliar primeiro as modificações fisiológicas ou físico-químicas da célula, fenômeno este conhecido como irritabilidade celular. Não apenas a presença, mas também a ausência de estímulos ocasiona a irritabilidade, como a impossibilidade de satisfazer as necessidades fisiológicas ou, nos humanos, a frustração real ou imaginária de um desejo. Este estado de irritabilidade predispõe à agressividade. Para Charles Darwin, "Se sofremos ou achamos que estamos na iminência de sofrer uma ofensa proposital de alguém, nutrimos contra ele uma antipatia que facilmente se transforma em ódio. "9

\title{
Para Karen Horney, apud Joaci Góes,
}

\begin{abstract}
A principal função do complexo papel do ódio é manter o odiento empeenhado na perseguição de objetivos inalcançáveis, em função de uma realização neurótica. Qualquer ameaça ou frustração de uma etapa dessa glória imaginária deflagra a ira que realimenta o odiento com a energia necessária para continuar perseguindo seus desejos, sendo quase infinita a variedade de modos pelos quais o ódio pode se manifestar. ${ }^{10}$
\end{abstract}

De outra banda, observa-se que o ódio é uma questão factual e sua intensidade como movimento transformador na sociedade dependerá de como ele é divulgado e enquanto o odiento não compreender que sua frustração é auto induzida e seu desespero um desperdício, ambos resultam na inútil obsessão em usar o ódio como mecanismo de transformação dos outros.

Dessa forma, enquanto as pessoas se mantiverem prisioneiras da ilusão de atos como o Holocausto, os genocídios em geral e toda sorte de violência que fere a dignidade da pessoa humana fruto de uma evitável insanidade mental, haverá condições de atuar no sentido de preveni-los ou erradicá-los.

Ademais, necessário ter presente que entre a frustração e o ódio, como entre o ódio e a agressão, existem a mente humana e a cultura na qual se está inserido, bem como que só a conscientização da necessidade de mudança poderá promover a alteração de paradigmas, base

\footnotetext{
${ }^{8}$ GLUCKSMANN, André. O Discurso do ódio. Rio de Janeiro: Difel, 2007. p.11.

${ }^{9}$ GOÉS, Joaci. Anatomia do Ódio. Rio de Janeiro: Topbooks, 2004. p. 28.
} 
fundamental da nossa conduta social. ${ }^{11}$ Para que o ódio seja, de fato, combatido é imprescindível que haja a consciência e a vontade de mudar do odiento, e que qualquer tipo de propagação nesse sentido seja coibida de forma eficaz, a fim de que não se torne uma conduta reiterada e que reste por violar direitos.

A seguir, verificar-se-á como o discurso de ódio tem adquirido proporção com o advento da sociedade da informação e como a internet tem sido meio de propagação de discriminações e violações de direitos fundamentais, em especial no que respeitam aos imigrantes, objeto do presente estudo.

\section{2 - SOCIEDADE DA INFORMAÇÃO: SOBERANIA DO OBJETO X SOBERANIA DO SUJEITO}

A Sociedade da informação pode ser compreendida como uma oportunidade histórica de concretização de direitos de cidadania, em específico das liberdades de informação e expressão, mas também como um cenário gerador de riscos ainda maiores no que concerne às desigualdades sociais no acesso à informação, violação da privacidade, fragilização e perda na segurança das transações, dentre outras violações de direitos fundamentais. ${ }^{12}$

$\mathrm{Na}$ sociedade da informação, Lash ao analisar os princípios estruturais da cultura global da informação, bem como os bens de consumo e os objetos que circulam através das redes globais, esclarece que na sociedade da informação as formas de vida se transformam em redes. Essas redes se caracterizam pela capacidade de estar em vários lugares ao mesmo tempo, na velocidade da informação, da comunicação, sua mercatilização e seu tratamento automático. Verifica-se a diferença entre as antigas estruturas da ordem industrial da informação, chamando atenção para o fato de que há a aparição de objetos e bens de consumo, bem como da autonomia dos mesmos, pois escapam ao controle dos sujeitos, através das redes globais, isto é, por fluxos, chamados símbolos, meios, migrantes, tecnologias, dinheiro. ${ }^{13}$

Trata-se, portanto, de um regime informacional emergente de poder. Nesse sentido, o referido autor indaga se é possível uma teoria crítica na sociedade da informação contemporânea? Ao respoder essas indagações, Lash questiona acerca da crítica da

\footnotetext{
${ }^{11}$ GOÉS, Joaci. Anatomia do Ódio. Rio de Janeiro: Topbooks, 2004. p. 274-297.

${ }^{12}$ GONÇALVES, Maria Eduarda. Direito da informação: novos direitos e formas de regulação na sociedade da informação. São Paulo: Almedina, 2003. p. 30.
} 
informação, bem como sobre os elementos básicos da ordem da informação, aludindo que as formas tecnológicas de vida, as formas de vida e suas noções, se converteram em tecnologia e ecoam consequências nas relações interpessoais, interinstitucionais, estatais e internacionais. 14

Na ordem da informação o poder não funciona a partir dos princípios informacionais, pois as formas de vida se desprendem de suas qualidades orgânicas e passam a funcionar como redes. Na sociedade em rede, as formas de vida estão de algum modo no ar, não arraigadas, trata-se de um ser do mundo, ser do planeta, dominado pela lógica da mercantilização. As formas de vida estão condicionadas à dinâmica da mercantilização e ambas essas dinâmicas estão subssumidas à lógica da informalização geral das redes. Na ordem da informação o poder atua sobre as bases da exploração e da exclusão. Essa visão crítica de Lash tem uma relação estreita com a análise feita por diversos teóricos quando discorrem acerca dos paradoxos afetos aos fluxos migratórios, pois é inegável que a mercantilização da vida, deu aos objetos maior valor que ao que deveria ser atribuído à vida humana e à própria natureza. ${ }^{15}$

Se na sociedade industrial nacional tinha-se por base o poder como exploração, a cultura global da informação depende do poder como exclusão. Na sociedade industrial nacional os principais atores eram as nações, instituições e organizações, já a sociedade da informação estabelece relações entre cidades globais de vários países. Há uma relação entre as relações internas de produção e as novas relações de produção e comunicação, o que gera no olhar de Lash, uma "desorganização". ${ }^{16}$

Lash faz uma crítica acerca do otimismo quanto à expansão dos horizontes pósindustriais e da inovação. Nesse aspecto, alerta que a teoria crítica deve ser também a teoria do poder, pois conforme aponta, existe um regime informacional emergente de poder. Há, portanto, uma soberania do objeto, dos produtos da sociedade da informação, retirando completamente a soberania do sujeito. Esses objetos soberanos, podem ora ser imagens, comunicações, finanças, ou seja, tudo que é efêmero e de alta rotatividade, uma marca, a aceleração, que possam representar a qualidade da informação e por isso escapa ao controle dos sujeitos e reproduz a lógica da mercantilização. ${ }^{17}$

\footnotetext{
${ }^{14}$ LASH, Scott. Crítica de la información. 1. ed. Buenos Aires: Amorrotu, 2005, p. 33-36.

${ }^{15}$ LASH, Scott. Crítica de la información. 1. ed. Buenos Aires: Amorrotu, 2005, p. 25-27.

${ }^{16}$ LASH, Scott. Crítica de la información. 1. ed. Buenos Aires: Amorrotu, 2005, p. 28.
} 
Essa teoria mediática, apresenta uma unidade cultural paradigmática onde a sociedade midiática, caracterizada pela necessidade de uma brevidade, velocidade natureza efêmera, se transforma em uma narração e discurso como princípio cardinal da cultura. Lash, ao abordar a teoria crítica, aponta para a dimensão do ser que é transcendental à ordem empírica da mercantilização, da linearidade e da racionalidade instrumental. Tem como principais investigações teóricas o Estado totalitário e a barbárie, a arte e a indústria cultural e a razão instrumental. ${ }^{18}$

Através da análise do sistema, da identidade e da racionalidade instrumental, elementos que constituem o reino do empírico, Lash estuda e identifica os meios de comunicação e a cultura industrial como causa da dependência e alienação dos homens, eis que transforma-o em consumidor passivo de mercadorias desprovidas da verdadeira essência, dentro de um sistema em que tudo se torna negócio e faz parte de um projeto de ideologia dominante onde a indústria ao fazer o elo entre a sociedade e a arte, gera o fenômeno que replica a arte e retira todo seu sentido, dando causa a uma alienação, desejo-fetiche, onde o homem perde a capacidade de pensar. ${ }^{19}$

É nesse viés que o migrante econômico enquanto produto mais ou menos valorizado no mercado, tem toda a sua soberania enquanto sujeito usurpada, eis que não é sequer sujeito de direitos, mas ocupa apenas o lugar de mais uma peça nessa engrenagem reprodutora de dominação econômica. Nesse sentido, a teoria crítica aponta a necessidade de uma mudança da semiótica, que seja baseada nas formas de socialização retirada na noção infundada e subsocializada do outro. A crítica a esse racionalismo abstrato, do espaço cartesiano dá espaço a uma semiótica estrutural.

Consoante leciona Redin, os sistemas simbólicos são instrumentos de conhecimento e de comunicação social, uma vez que representam um poder de construir uma realidade e estabelecer um sentido imediato de mundo. Essas produções simbólicas funcionam como instrumentos de dominação, por uma cultura que ora une (intermediário de comunicação), ora separa (instrumento de distinção). Nesse contexto, o sistema global e capitalista que massifica a sociedade e naturaliza as fronteiras do Estado-nação sob a perspectiva do mercado, tornam o sujeito mero objeto nas redes fronteiriças de produção. ${ }^{20}$

\footnotetext{
${ }^{18}$ LASH, Scott. Crítica de la información. 1. ed. Buenos Aires: Amorrotu, 2005, p. 46.

${ }^{19}$ LASH, Scott. Crítica de la información. 1. ed. Buenos Aires: Amorrotu, 2005, $42-43$.

${ }^{20}$ REDIN, Giuliana. Direito de Imigrar- Direitos Humanos e Espaço Público. Florianópolis: Conceito Editorial 2013, p. 49.
} 
Lash chama atenção para o fato de que a sociedade da informação (sociedade reflexiva), é em verdade uma sociedade desinformada, na medida que a sobrecarga de informação produz desinformação, razão pela qual supõe níveis muito altos de reflexividade. $\mathrm{Na}$ ordem da informação, o poder é não linear e descontínuo, de sistemas tecnológicos e não orgânicos. A acumulação de capital também é acumulação de forma de vida como informações nas bases de dados, onde cresce o patenteamento de propriedades intelectuais. Se na sociedade industrial havia uma vinculação recíproca entre os sujeitos e objetos, numa relação de causa e efeito, na sociedade da cultura tecnológica há uma relação de aditividade, hipercausalidade, mais casual do que causal, uma reflexividade. ${ }^{21}$

Esses sistemas simbólicos, que geram dominação, também têm o poder de causar uma desinformação e indiferença. A sociedade moderna padece de uma desinformação crônica no que respeitam às consequências da realidade do outro, pois a noção de uma cidadania global de fato não passa de um sentimento de interação e integração com o todo, desde que esse todo contenha valor de troca ou de uso, mas na medida em que o espaço possa ser ocupado por algo que não represente ganhos diretos ou colaterais, a vida sequer tem valor, é variável independente na matemática do poder. Situação essa observada no que respeitam as manifestações de alguns internautas com relação a imigração no mediterrâneo e as tragédias dela decorrentes, bem como as mazelas enfrentadas pelos imigrantes que chegam ao Brasil, que revelam verdadeiro desprezo a vida humana, pois encontram justiça na própria torpeza do colonizador face ao colonizado.

Adiante observa-se-á como essa lógica da soberania do objeto (notícia) se sobrepõe a soberania do sujeito (imigrante), na medida em que os discursos de ódio proferidos contra o imigrante na internet, desconsideram friamente a condição humana e suas mazelas, para dar maior enfoque às questões de cunho econômico, de segurança nacional, discriminação e xenofobia, apontando para uma sociedade da informação onde paira uma sensação de total desregulamentação e ausência de proteção de direitos fundamentais.

\section{3 - INTERNET E OS DISCURSOS DE ÓDIO AOS IMIGRANTES}

É cada vez mais comum a propagação de discursos de ódio nas redes sociais ${ }^{22}$, tão utilizadas atualmente como meio de expressão individual. Nesse cenário, faz-se

\footnotetext{
${ }^{21}$ LASH, Scott. Crítica de la información. 1. ed. Buenos Aires: Amorrotu, 2005, p. 44-46.

${ }^{22}$ Entende-se por rede social como um conjunto de dois elementos: atores (pessoas, instituições ou grupos; os nós da rede) e suas conexões. Nesse sentido: "É uma metáfora para observar os padrões de conexão de um grupo social, a partir das conexões estabelecidas entre os diversos atores. A abordagem de rede tem, assim, seu foco na
} 
imprescindível um questionamento sobre os limites dessas práticas, que podem estar ferindo o direito de quem é alvo desses discursos e, em específico os imigrantes, objeto do presente estudo.

O Brasil, desde a sua colonização, tem sido destino de fluxos migratórios. Contudo, nos últimos anos as redes de imigrantes que buscam aqui novas oportunidades de vida, tem sofrido uma forma de discriminação que os imigrantes anteriores ao advento da sociedade da informação não haviam experimentado, tratam-se, pois, de verdadeiras manifestações odiosas no âmbito da internet que desafiam não só o espaço e o tempo global, mas ignoram qualquer limitação de ordem legal à violação de direitos fundamentais da pessoa humana.

Observa-se ainda que várias das manifestações ${ }^{23}$ odiosas apresentam caráter criminoso, pois além de revelar clara xenofobia, também fazem relação direta do imigrante com grupos criminosos, de guerrilha paramilitar, bem como ligação com partido e ideologia partidária, atribuindo ao imigrante inúmeras insatisfações de ordem pessoal, social e política $^{24}$.

Em junho do corrente ano, Daniel Barbosa gravou vídeo e postou nas redes sociais, onde ofende imigrante haitiano que trabalha como frentista em um posto de Canoas, na região Metropolitana de Porto Alegre. O teor da gravação consiste em constranger o imigrante associando sua vinda ao Brasil a redes criminosas, questionando se passou por treinamento militar, momento em que ironiza "Ele não tem treinamento militar e foi trazido pelos comunistas aqui no Brasil" e em seguida diz que o frentista "tem muita sorte" e "é muito competente" por estar empregado. O ofendido não reage e o ofensor continua seu discurso xenofóbico alegando que "a vinda de imigrantes do Haiti para a América do Sul, foi promovida pelo governo comunista de Dilma Rousseff enquanto milhares, só no mês passado, de brasileiros, perderam o emprego no Brasil. ” Durante a gravação, Barbosa fala que já estamos em guerra. Ao final do vídeo é observada a inscrição: "Cruzada pela Liberdade. Por um Brasil livre, ético e digno". ${ }^{25}$

Na mesma toada, em busca realizada na internet associando os termos imigração no Brasil, xenofobia, discursos de ódios e movimento nacionalista e/ou patrióticos, pode ser verificado a seguinte postagem em página no Facebook denominada "Movimento Nacionalista Brasileiro":

estrutura social, onde não é possível isolar os atores sociais e nem suas conexões.” RECUERO, Raquel. Redes Sociais na internet. Porto Alegre: Sulina, 2009. p. 24.

${ }^{23}$ Manifestações extraídas a partir da busca na rede mundial de computadores utilizando-se dos seguintes elementos de busca: imigrantes no Brasil; xenofobia; discursos de ódio.

${ }^{24}$ Notícias analisadas para o presente artigo podem ser conferidas nos links disponíveis no anexo.

${ }^{25}$ Disponível em https://www.youtube.com/watch?v=WOSZu40swU8 


\begin{abstract}
A quantidade absurda de imigrantes que não possuem maneiras de se manter em nosso país, principalmente os haitianos é preocupante. Nossa nação está sofrendo uma grave crise econômica e esses povos continuam a invadir nossa terra, mais de 1000 haitianos já foram mandados para São Paulo, sem contar o de outras regiões, e o governo de São Paulo já pretende fornecer o bolsa família para estes imigrantes que roubam o emprego de milhares de brasileiros que já estão sofrendo com as taxas altíssimas de desemprego crescentes e recebem menos benefícios por parte do governo do que essa corja de imigrantes que chegam sem controle nenhum a nosso país. Sinceramente é necessário conscientizar o povo dos problemas ainda maiores que isso pode causar em nossa econômia e fazer o governo ouvir nossa voz e impedir que continuem vindo e roubando nossas terras e acabando com o pouco da cultura brasileira que ainda resta! ${ }^{26}$
\end{abstract}

Na mesma senda na edição 31 de maio do corrente ano do jornal Zero Hora, veículo do Rio Grande do Sul, onde Roberto Fróes Pena manifesta sua opinião acerca da vinda de imigrantes haitianos e senegaleses para o Brasil, alegando que em nada tem para contribuir com o país, pois

\footnotetext{
“é comprovado que pessoas com pouca ou quase nada de formação profissional e cultural, tem uma tendência natural de caírem para o lado do crime, roubo, tráfico e fatalmente vão ocupar vagas nos presídios. A prova disso foram os escravos que vieram para o Brasil (negros) que chegaram sem nenhuma formação nem cultura, e proporcionalmente hoje ocupam a maioria das vagas hoje nos presídios"27
}

O jornal Gazeta do Povo $^{28}$ com pagína na internet, apresenta levantamento de 10 comentários que curitibanos fizeram no Facebook contra a imigração dos haitianos para o Brasil, em especial para a cidade de Curitiba. Os comentários se deram em razão do fato de que a prefeitura da capital do Paraná ter feito um post no Facebook como desagravo pelas discriminações sofridas pelos imigrantes naquela cidade, com o título "Que o Haiti seja aqui", o texto começa em francês, dizendo que os haitianos são bem-vindos e critica a xenofobia Haitiens, bienvenu a Curitiba! Le Conseil de la Ville travaille toujours pour l'inclusion sociale et culturelle pour tous. A xenofobia é crime. E é uma vergonha. Os verdadeiros curitibanos, oriundos de múltiplas etnias, devem dar exemplo de convivência pacífica e de respeito. O texto teve 13 mil curtidas, muitos compartilhamentos e centenas de comentários tanto de apoio à iniciativa da prefeitura e aos haitianos. Porém recebeu inúmeros comentários com

\footnotetext{
${ }^{26}$ Disponível em:

<https://www.facebook.com/permalink.php?story_fbid=966244823406058\&id=902871299743411>

${ }^{27}$ Disponível em: http://www.cartacapital.com.br/sociedade/zero-hora-vamos-falar-de-racismo-6431.html

${ }^{28}$ Manifestações extraídas a partir da busca na rede mundial de computadores utilizando-se dos seguintes elementos de busca: imigrantes no Brasil; xenofobia; discursos de ódio.
} 
discursos de ódio e xenofobia explícitos, inclusive afirmando que “... Curitiba realmente era muito melhor e mais segura antes da onda de imigração nordestinos, cariocas e haitianos..." 29

Verifica-se claramente que as manifestações odiosas acima, dentre outras que podem ser conferidas no anexo constante deste artigo, encontram semelhanças na estrutura discursiva, apresentando sempre um teor racista, discriminatório e preconceituoso em relação ao imigrante, pois trata-se de discriminação exaurida por meio de manifestação que segrega, onde é estabelecida uma diferenciação hierárquica entre emissor (superior) e receptor (inferior), e a manifestação toma dimensões além do conhecimento de quem a propaga, ${ }^{30}$ sobretudo porque tem na internet um veículo de alcance e velocidade ilimitado. Há, como pode ser observado, uma assincronia no que respeita o alcance e velocidade da viloção sofrida e garantia de proteção dos direitos daqueles que tem sua dignidade solapada, mormente se for considerado que no caso do ofendido/imigrante sua situação de hipossuficência já é tão aquém do miníno, que muitas vezes sequer lhe permite buscar os direitos de reparação.

É nesse sentido que buscar-se-á demonstrar a seguir a necessidade não só de esclarecer quanto aos limites da liberdade de expressão, mas também apontar caminhos para a construção de uma sociedade da informação que cumpra uma função social, valendo-se do aporte da interculturalidade ${ }^{31}$, como forma de coibir e inibir manifestações odiosas.

\subsection{Limites da Liberdade de Expressão e Função Social da Internet}

Como visto alhures, ainda que o artigo 20 da Lei 7.716/89 puna aquele que praticar, induzir ou incitar a discriminação ou preconceito de raça, cor, etnia, religião ou procedência nacional com pena de reclusão, que pode variar de 1 a 3 anos e multa, agravando ainda a pena se o crime for cometido por intermédio dos meios de comunicação como a Internet (agravada de 2 a 5 anos e multa, conforme o parágrafo $2^{\circ}$ da mesma Lei), verifica-se que o tipo penal em referência não tem sido suficiente para inibir os discursos de ódio na rede mundial de

29 Disponível em: http://www.gazetadopovo.com.br/blogs/caixa-zero/10-comentarios-que-curitibanos-fizeramno-facebook-contra-a-imigracao-dos-haitianos/

30 SILVA, Rosane Leal da; NICHEL, Andressa; MARTINS, Anna Clara Lehmann; BORCHARDT, CarliseKolbe. Discursos de ódio em redes sociais: jurisprudência brasileira. Revista Direito GV, São Paulo, vol. 14, n. 2, p. 445-468, jul-dez 2011.

${ }^{31}$ Canclini aborda a interculturalidade sob a ótica e a conceitualização de hibridação, aduzindo que designar as misturas interculturais propriamente modernas, entre outras, aquelas geradas pelas integrações dos Estados nacionais, os populismos políticos e as indústrias culturais. A hibridação conceitua os processos derivados da interculturalidade, e contempla um conceito de maior amplitude que presta-se a conceituar os processos contemporâneos de entrelaçamento de culturas não apenas as combinações de elementos étnicos ou religiosos, mas também a de produtos de tecnologia avançadas. Assim, interculturalidade neste sentido, é tida como um processo de hibridização, de entrelaçamento de culturas dentro de uma comunidade. CANCLINI, Nestor Garcia. Diferentes, Desiguais e Desconectados. Rio de Janeiro: Editora UFRJ, 2009. p. 29. 
computadores, o que demonstra que na sociedade da informação ainda paira um sentimento de que seu âmbito ocorre à margem do Direito.

Nesse sentido, Perez Luño, ressalta que na era da internet, uma das maiores preocupações, consiste em estabelecer uma equação exata entre os avanços tecnológicos e a tutela das liberdades, eis que "El ámbito del mundo, cada vez más planetario, ha apretado decisivamente sus exigencias y reclama un adecuado planteamiento de las garantías de los derechos cívicos ante el desarrollo de las Nuevas Tecnologías (NT)". ${ }^{32}$

Nesse viés, aludido autor chama atenção para o fato de que as redes de informação e comunicação nos âmbitos jurídicos e políticos tem reclamado que se adquira uma consciência de se conceber valores e direitos da pessoa humana como garantias universais e essa reinvindicação de universalidade de direitos devem ser tutelados protegendo de qualquer discriminação, seja por razões de raça, língua, sexo, religião ou convicções ideológicas ou manipulações de poder.

Essa preocupação não é apenas de ordem interna dos Estados, mas devem ser pauta das agendas internacionais, na medida que se afirma que

Se siente hoy con mayor intensidad que en cualquier etapa histórica precedente, la exigencia de que los derechos y las libertades no se vean comprometidos por el tránsito de las fronteras estatales; lo que implica tomar en serio el compromiso en pro de la ciudadanía cosmopolita. ${ }^{33}$

Combater e desconstruir a discriminação difundida nas redes sociais torna-se uma tarefa hercúlia, mormente se for considerado que as lides que versam sobre manifestações odiosas na sua maioria remontam a discriminações veladas e estereótipos que foram se arraigando no imaginário e desdobrando-se em práticas discriminatórias que parecem ter sido naturalizadas, dado seu caráter "tradicional". Samantha Meyer-Pflug esclarece ainda que as manifestações do discurso do ódio podem ser originadas tanto da livre expressão do pensamento quanto de grupos que sofreram algum dano ao longo da história e, em consequência disso, proferem palavras e opiniões odiosas como num ato de revanche. ${ }^{34}$

Assim, para estabelecer a igualdade de fato e não somente a formal, é necessário que se estabeleçam ações afirmativas (denominadas também de discriminação positiva) e inclusivas

\footnotetext{
${ }^{32}$ LUÑO, Antonio-Enrique Pérez. Internet y los derechos humanos. Disponível em: <http://dialnet.unirioja.es/servlet/articulo?codigo=995024\&orden=25231\&info=link>. Acesso em: 19 jun. 2015. P. 101.

33 LUÑO, Antonio-Enrique Pérez. Internet y los derechos humanos. Disponível em: <http://dialnet.unirioja.es/servlet/articulo?codigo=995024\&orden=25231\&info=link>. Acesso em: 05 fev. 2013. p. 102.

${ }^{34}$ MEYER-PFLUG, Samantha Ribeiro. Liberdade de Expressão e Discurso de Ódio. São Paulo, Ed. Revista dos Tribunais, 2009. p. 98-101.
} 
para nivelar as desigualdades e inserir na sociedade esses grupos outrora segregados ${ }^{35}$. Necessário pois, uma sociedade da informação que cumpra sua função social.

No que toca a discriminação, esta é "mais forte do que a simples diferença, pois ela é utilizada em um sentido pejorativo e tem por fundamento critérios ilegítimos, normalmente relacionados à ideia de superioridade de um grupo em relação ao outro". ${ }^{36}$ Cumpre observar que "está-se diante de uma situação de discriminação quando um determinado grupo, segundo critérios adotados naquela sociedade, deve receber um determinado tratamento isonômico e não o obtém, porque uma parcela da sociedade entende que eles não fazem jus a esse tratamento".37

Nesse aspecto, como alude Tomaz Tadeu a teorização cultural contemporânea pertinente a identidade e a diferença não pode apenas ser abordada sob o viés do multiculturalismo, pois é inegável que aquelas fazem parte do processo de produção social e que envolvem diretamente relações de poder, eis que não se reduzem a relações de consenso, diálogo ou comunicação, pois tem a ver com a atribuição de sentido ao mundo social e com a disputa e luta em torno dessa atribuição. ${ }^{38}$

O preconceito traduzido no discurso do ódio, que muitas vezes é feito de forma indireta e travestido pela prática de caricaturar pessoas e comportamentos, toma dimensões incalculáveis, pois não se restringe à violação dos direitos fundamentais dos indivíduos-alvo, mas de todo um grupo social. O preconceito é uma opinião equivocada, considerada como verdadeira por determinadas pessoas, porém ressalta que nem toda manifestação equivocada pode ser considerada como preconceito, eis que este se diferencia em duas classes: enquanto os preconceitos individuais estão relacionados às crenças e às superstições, os sociais são aplicados por um determinado grupo social contra outro, sendo que o mais grave é o preconceito social, pois tem o poder de disseminar até mesmo guerras. ${ }^{39}$

Quanto às consequências do preconceito, Samantha Meyer-Pflug, alerta:

são inúmeras, uma delas é a discriminação jurídica, pois a despeito de assegurar [...] o princípio da isonomia, alguns cidadãos são excluídos da fruição de determinados

\footnotetext{
${ }^{35}$ MEYER-PFLUG, Samantha Ribeiro. Liberdade de Expressão e Discurso de Ódio. São Paulo, Ed. Revista dos Tribunais, 2009. p. 101.

${ }^{36}$ MEYER-PFLUG, Samantha Ribeiro. Liberdade de Expressão e Discurso de Ódio. São Paulo, Ed. Revista dos Tribunais, 2009. p. 109-110.

${ }^{37}$ MEYER-PFLUG, Samantha Ribeiro. Liberdade de Expressão e Discurso de Ódio. São Paulo, Ed. Revista dos Tribunais, 2009. p. 111.

${ }^{38}$ SILVA, Tomaz Tadeu da (Org.). Identidade e diferença: a perspectiva dos estudos culturais. 9. ed. Rio de Janeiro: Vozes, 2009.

${ }^{39}$ MEYER-PFLUG, Samantha Ribeiro. Liberdade de Expressão e Discurso de Ódio. São Paulo, Ed. Revista dos Tribunais, 2009. p. 104.
} 
direitos. Outra consequência é a marginalização social, ou seja, esses grupos ficam isolados do convívio social. ${ }^{40}$

Nesse sentido, Tomaz Tadeu alerta que as relações de poder ocorrem em um cenário onde os processos de produção social tem na identidade elemento instável, contraditório, fragmentado, inconsistente e inacabado, pois está diretamente ligado a estruturas discursivas e narrativas, a sistemas de representação, ou seja, tem conexões estreitas com relações de poder. $^{41}$

Perez Luño ressalta a necessidade do estabelecimento de garantias que tutelem os indivíduos frente à agressão tecnológica da sua identidade, devendo as estruturas jurídicas e políticas do Estado

...ter interesse prioritario en una sociedad en la que el poder de la información ha adquirido una importancia capital y la que la faculdade de comunicación y de acceso a la información aparece como una forma irrenunciable de libertad. ${ }^{42}$

O autor supra, salienta que o excesso de informação nas mãos do governo, bem como da iniciativa privada, pode ensejar um implacável fenômeno de manipulação e controle social, perigos que podem ser acrescidos por problemas políticos, econômicos de manutenção de poder, tanto no âmbito interno quanto internacional e que situações críticas poderiam ensejar a suspensão generalizada de direitos fundamentais e como alude o autor ... Y no puede descartarse el peligro que esas medidas de excepcíon violadoras de los derechos humanos acabaran por convertirse, con el argumento de su carater preventivo, en moneda corriente para la conviveencia. ${ }^{43}$

Imperioso refletir que da mesma forma que Thomas Hobbes explicava o Estado moderno como uma grande metáfora biológica, o Leviatã, hoje pode-se dizer que ... es el

Estado gobernado por medio de computadoras, o incluso por máquinas antropomórficas: los

\footnotetext{
${ }^{40}$ MEYER-PFLUG, Samantha Ribeiro. Liberdade de Expressão e Discurso de Ódio. São Paulo, Ed. Revista dos Tribunais, 2009. p. 108.

${ }^{41}$ SILVA, Tomaz Tadeu da (Org.). Identidade e diferença: a perspectiva dos estudos culturais. 9. ed. Rio de Janeiro: Vozes, 2009. p. 97.

42 PÉREZ LUÑO, Antonio-Enrique. Informática y libertad. Comentario al articulo 18.4 de la constitución española. Disponível em: < http://dialnet.unirioja.es/servlet/articulo?codigo=26680\&orden=0\&info=link>. 05 fev. 2013, p. 34.

${ }^{43}$ PÉREZ LUÑO, Antonio-Enrique. Informática y libertad. Comentario al articulo 18.4 de la constitución española. Disponível em: < http://dialnet.unirioja.es/servlet/articulo?codigo=26680\&orden=0\&info=link>. 05 fev. 2013, p. 37.
} 
robots, a internet tem assumido, na sociedade tecnológica, o papel simbólico de uma nova condição de vida coletiva, sendo ela o novo Leviatã da segunda metade do século XX ${ }^{44}$

Sugere-se, portanto, um equilíbrio entre os poderes estatais e o fortalecimento da sociedade civil, sendo a informática, para o bem ou para o mal, um dos principais ingredientes desse equilíbrio, onde não só o Estado e seus demais poderes, as entidades privadas detentoras da tecnologia possam intervir nesse cenário, mas também a sociedade e cada indivíduo participante possa opinar e interagir nesse processo, Se trata de establecer garantías del control de los controladores. ${ }^{45}$

O Estado tem um papel determinante diante desse contexto, pois, através de sua função jurisdicional e de políticas públicas de educação, promoção da solidariedade, deve dar tratamento constitucionalmente adequado a discursos de intolerância, de modo a fomentar uma sociedade da informação/internet que cumpra sua função social, protegendo a dignidade da pessoa humana, porém sem violar a liberdade de expressão e preservando o Estado Democrático de Direito

Como frisou o Ministro Celso de Mello, no julgamento do Habeas Corpus 82424-2, do caso de Sigfried Ellwanger que escreveu e publicou livros pregando e justificando o ódio aos judeus:

[...] Os postulados da igualdade e da dignidade pessoal dos seres humanos, constitui limitações externas à liberdade de expressão, que não pode e não deve ser exercido com propósito subalterno de veicular prática criminosa tendentes a fomentar e a estimular situações de intolerância e de ódio público. [... $]^{46}$

Daniel Sarmento, discutindo as "pré-compreensões", salienta que a nova hermenêutica ressalta o papel central desempenhado pela pré-compreensão dos aplicadores do direito, partindo-se da premissa de que nenhum ser humano habita um vazio axiológicocultural, pois são seres enraizados, que compartilham ideias, valores, preconceitos com os seus semelhantes, não se despindo deles no momento de interpretar e aplicar o direito. Reforça ainda que a aposta hermenêutica na pré-compreensão parece ignorar o fato de que as

${ }^{44}$ PÉREZ LUÑO, Antonio-Enrique. Informática y libertad. Comentario al articulo 18.4 de la constitución española. Disponível em: < http://dialnet.unirioja.es/servlet/articulo?codigo=26680\&orden=0\&info=link>. 05 fev. 2013, p. 38.

${ }^{45}$ PÉREZ LUÑO, Antonio-Enrique. Informática y libertad. Comentario al articulo 18.4 de la constitución española. Disponível em: < http://dialnet.unirioja.es/servlet/articulo?codigo=26680\&orden=0\&info=link>. 05 fev. 2013, p. 40.

46 BRASIL. Supremo Tribunal Federal. Habeas Corpus 82424-2. Partes: Siegfried Ellwanger; Werner Cantalício; João Becker.Relator: Min. MOREIRA ALVES, 17 de setembro de 2003. Disponível em: < http://stf.jusbrasil.com.br/jurisprudencia/770347/habeas-corpus-hc-82424-rs>. Acesso em: 18 abr. 2015. 
tradições e práticas sociais estão encharcadas de opressão, de estereótipos negativos e de preconceitos, que se encontram tão profundamente enraizados, que o indivíduo até perde a capacidade de enxergá-los. Nas palavras do referido autor: Convivemos por tanto tempo com algumas formas de injustiças que tendemos todos - inclusive suas vítimas - a naturalizá-las, incorporando-as aos nossos padrões de normalidade. Nossas tradições as tornam invisíveis. ${ }^{47}$

Importante frisar que nenhuma cultura ou tradição específica tem o condão de relativizar outros saberes, culturas a ponto de estabelecer e padronizar um império de valores e verdades imutáveis. A sociedade da informação através das novas tecnologias conecta não só todas as partes do mundo, mas deve também estabelecer comunicações interativas, com um olhar aberto para outras culturas e formas de vida, pois a multiplicidade de sistemas e de representação do mundo pode identificar ao menos temporariamente os sujeitos e por isso merecem ser consideradas. $^{48}$

O dever geral de respeito à pessoa no que se refere a sua qualidade intrínseca de ser humano, resultante do direito da dignidade da pessoa humana, impõe que não sejam admitidas quaisquer condutas que, em nome do direito à liberdade de expressão, restem por discriminar qualquer indivíduo ou grupo social. O direito de autodeterminar-se e reconhecer-se como pessoa parte de um dado grupo social, religião, opinião política, raça, cor, orientação sexual, procedência nacional ou regional, é direito personalíssimo e advém dos direitos da personalidade, por isso imprescindíveis para a construção de uma sociedade justa, livre e igualitária.

Essa sujeição de direitos, na esfera do conceito de direitos humanos, deve ser respeitada, sem que haja qualquer hierarquização. Afirma Canclini que "adotar uma perspectiva intercultural proporciona vantagens epistemológicas e de equilíbrio descritivo e interpretativo, leva a conceber as políticas da diferença não só como necessidade de resistir." e que "As teorias comunicacionais nos lembram que a conexão e a desconexão com os outros são parte da nossa constituição como sujeitos individuais e coletivos. Portanto, o espaço inter

\footnotetext{
47 SARMENTO, Daniel. Liberdade de expressão, pluralismo e o papel promocional do Estado. Revista Diálogo Jurídico, Salvador, $\mathrm{n}^{\circ}$. 16 maio-junho-julho-agosto, 2007. Disponível em: <http://www.direitopublico.com.br>. Acesso em: 27 de fev. 2012. p. 220 - 222.

${ }^{48}$ LUCAS, Doglas César. Direitos Humanos e Interculturalidade: um diálogo entre a igualdade e a diferença. Ijuí: Editora Unijuí, 2010. p. 166-229.
} 
é decisivo", eis que como o referido autor afirma, interculturalidade significa que os diferentes são o que são, em relações de negociação, conflito e empréstimos recíprocos. ${ }^{49}$

Perez Luño aponta que a relação entre os avanços tecnológicos e a tutela das liberdades, reclama um adequado enfoque no que respeitam às garantias e direitos fundamentais, eis que a presença das redes de informação nos âmbitos jurídicos e políticos tem determinado que se adote uma consciência da necessidade de valores e direitos da pessoa como garantias universais. Um diálogo fluido entre o universo tecnológico e a esfera dos direitos humanos, sob pena de que a técnica seja mera forma oca, como a lógica mais formalista e incapaz de determinar o conteúdo da vida. ${ }^{50}$

Conforme salienta Perez Luño à luz de Frosini, a urgência é de uma "consciência tecnológica" dos juristas e politólogos diante do impacto da internet nos sistemas jurídicos atuais, de modo que haja uma reflexão crítica e responsável ante aos novos problemas que a tecnologia suscita e os desafios estabelecidos ao Direito e aos Direitos Humanos, eis que no ciberespaço, não existem fronteiras, distâncias ou autoridade centralizada. ${ }^{51}$

Perez Luño, lembrando as lições de Sunstein, adverte acerca da consequência negativa do exercício da cidadania na internet, corresponde a uma cidadania.com que tem como palco a República.com, eis que o internauta, na condição de cidadão, deve assumir uma postura solidária e não reduzir-se a mero usuário-consumidor onde seus interesses são os únicos que prevalecem e são meros reprodutores da lógica econômica de mercado, abandonam sua condição de sujeitos políticos ativos e restam degradados a consumidores passivos de produtos advindos dos grandes poderes econômicos. ${ }^{52}$

Nesse sentido o autor em questão afirma que

La Red, en definitiva, puede ser el principal cauce para promover una participación política más auténtica, plena y efectiva en las democracias del siglo XXI, en términos de ciberciudadanía; o para degenerar en un fenómeno de colonización y

\footnotetext{
${ }^{49}$ CANCLINI, Nestor Garcia. Diferentes, Desiguais e Desconectados. Rio de Janeiro: Editora UFRJ, 2009. p. 25-31.

50 LUÑO, Antonio-Enrique Pérez.. Internet y los derechos humanos. Disponível em: $<$ http://dialnet.unirioja.es/servlet/articulo?codigo=995024\&orden=25231\&info=link>. Acesso em: 05 fev. 2013. p. 101-102.

51 LUÑO, Antonio-Enrique Pérez.. Internet y los derechos humanos. Disponível em: <http://dialnet.unirioja.es/servlet/articulo?codigo=995024\&orden=25231\&info=link>. Acesso em: 05 fev. 2013. p. $103-114$.

52 LUÑO, Antonio-Enrique Pérez.. Internet y los derechos humanos. Disponível em: <http://dialnet.unirioja.es/servlet/articulo?codigo=995024\&orden=25231\&info=link>. Acesso em: 05 fev. 2013. p. 114.
} 
control de la vida cívica, quedando degradada en versiones indeseables de ciudadanía.com. ${ }^{53}$

A circulação de informação além de transcender fronteiras e idiomas, também implica em desafio às políticas culturais, sociais e inclusive jurídicas, pois quem possui a informação, possui poder. Nesse sentido, importante salientar a necessidade que a sociedade da informação possua também uma função social, pois não basta fazer parte dela e se servir de suas benesses, há que saber como utilizá-la para que se alcance aspirações e benefícios em prol do bem comum. ${ }^{54}$

\section{CONSIDERAÇÕES FINAIS}

O presente artigo se propôs a analisar manisfetações odiosas contra imigrantes no Brasil, em específico no âmbito da sociedade da informação e sua dinâmica frente ao paradoxo da soberania do objeto $\mathrm{x}$ soberania do sujeito. Verificou-se pelos casos emblemáticos, que os mesmos apresentam elementos semelhantes que compõem essa estrutura, como por exemplo o completo desconhecimento da realidade do outro, refletidos na ausência de alteridade, a discriminação e preconceito muitas vezes externalizados e caracterizados por atos de verdadeira xenofobia, bem como um sentimento de total prevalência da liberdade de expressão sem respeito aos seus limites, inclusive legais, o que aponta para um crítico quadro em que grande parte dos usuários da rede mundial de computadores no Brasil ainda tem a perspectiva de que o ambiente virtual está de fato à margem do Direito.

Nesse sentido, o estudo realizado aguçou ainda mais incertezas acerca da problemática discurso de ódio, sociedade da informação e Direito, pois como analisado, a internet hoje reflete como um espelho as complexidades e conflitos das relações sociais, funcionando como um termômetro na identificação de discriminações, preconceitos e discursos de ódio, no âmbito de uma sociedade como o Brasil que até então era conhecida internacionalmente como receptiva, solidária e plural.

A pré-compreensão e a hermenêutica acerca da estrutura de construção dos discursos de ódio como visto, reclama a existência de uma função social da internet, não podendo ser

\footnotetext{
53 LUÑO, Antonio-Enrique Pérez. Internet y los derechos humanos. Disponível em: <http://dialnet.unirioja.es/servlet/articulo?codigo=995024\&orden=25231\&info=link>. Acesso em: 05 fev. 2013. p. 118.

${ }^{54}$ COBO, Dolores Lavalle. Derecho de acceso a la información pública. Editorial Astrea. Ciudad de Buenos Aires: 2009.
} 
reduzida a um fim em si mesma ou instrumento de violação de direitos, mas também funcionando como ferramenta de visibilidade e respeito ao outro. Faz-se necessário combater a falsa ideia de que essas manifestações odiosas não são alcançadas pelo ordenamento jurídico, pois diante desse cenário de tantas incertezas, permanecem como aventado alhures, inúmeros questionamentos, dentre eles: há uma lacuna normativa quanto ao discurso de ódio ou seria apenas uma questão de hermenêutica? Será que essas manifestações assumiram feições de atos banais e naturais e estão tão arraigadas que passam desapercebidas por aqueles que as emanam e tão irrelevantes por aqueles que deveriam proteger a dignidade da pessoa humana? Essa deficiência existe e como supri-la?

Essas angústias apontam no sentido de que a proteção da dignidade da pessoa humana merece maior atenção no âmbito da internet, daí a necessidade de que a mesma exerça, sobretudo, sua função social como forma de inibir e coibir discursos de ódio. $\mathrm{O}$ Direito deve apontar o caminho para que essa função social seja cumprida, ocupando o Estado um importante papel no sentido de implementar políticas pluralistas e de interculturalidade, valendo-se do diferencial quanto ao alcance, abrangência e velocidade característicos do ciberespaço, pois como visto a simples existência de um tipo penal que puna manifestações odiosas na rede, não intimida e nem impede a reiteração do ato daquele que profere discurso discriminatório.

Como observado, esses conflitos que entrecruzam o Direito e a tecnologia ainda não conseguem ser suficientemente resolvidos apenas pela existência de uma lei. A reiteração de discursos de ódio contra os imigrantes no Brasil desafia todo o sistema jurídico e a sociedade à complexidade da compreensão da identidade, da diferença, ao reconhecimento da diversidade, da pluralidade. $\mathrm{O}$ que de fato pode ter o poder de modificar esse cenário, trazido do mundo real para o virtual, é a possibilidade de troca de saberes, culturas e valorização da realidade do outro a partir da alteridade, sendo exatamente essa a função social que se almeja na atual sociedade da informação.

\section{REFERÊNCIAS}

ARENDT, Hannah. Origens do Totalitarismo: antissemitismo, imperialismo e totalitarismo. São Paulo: Companhia de Bolso. 2012.

BIRMAN, Joel. Cadernos sobre o mal: agressividade, violência e crueldade. Rio de Janeiro: Civilização Brasileira, 2009. 
BRASIL. Supremo Tribunal Federal. Habeas Corpus 82424-2. Partes: Siegfried Ellwanger; Werner Cantalício; João Becker.Relator: Min. MOREIRA ALVES, 17 de setembro de 2003. Disponível em: < http://stf.jusbrasil.com.br/jurisprudencia/770347/habeas-corpus-hc-82424rs>. Acesso em: 18 abr. 2015.

CANCLINI, Nestor Garcia. Diferentes, Desiguais e Desconectados. Rio de Janeiro: Editora UFRJ, 2009.

COBO, Dolores Lavalle. Derecho de acceso a la información pública. Editorial Astrea. Ciudad de Buenos Aires: 2009.

GOÉS, Joaci. Anatomia do Ódio. Rio de Janeiro: Topbooks, 2004.

GONÇALVES, Maria Eduarda. Direito da informação: novos direitos e formas de regulação na sociedade da informação. São Paulo: Almedina, 2003. p. 7.

GLUCKSMANN, André. O Discurso do ódio. Rio de Janeiro: Difel, 2007.

LASH, Scott. Crítica de la información. 1. ed. Buenos Aires: Amorrotu, 2005.

LUCAS, Doglas César. Direitos Humanos e Interculturalidade: um diálogo entre a igualdade e a diferença. Ijuí: Editora Unijuí, 2010.

MICHELMAN, Frank. Relações entre democracia e liberdade de expressão: discussão e alguns argumentos. In: SARLET, Ingo Wolfgang; MICHELMAN, Frank (orgs.). Direitos Fundamentais, Informática e Comunicação: algumas aproximações. Porto Alegre: Livraria do Advogado. 2007.

LUÑO, Antonio-Enrique Pérez. Internet y los derechos humanos. Disponível em: $<$ http://dialnet.unirioja.es/servlet/articulo?codigo=995024\&orden=25231\&info=link>. Acesso em: 05 fev. 2013.

MEYER-PFLUG, Samantha Ribeiro. Liberdade de Expressão e Discurso de Ódio. São Paulo, Ed. Revista dos Tribunais, 2009.

RECUERO, Raquel. Redes Sociais na internet. Porto Alegre: Sulina, 2009.

REDIN, Giuliana. Direito de Imigrar: Direitos Humanos e Espaço Público. Florianópolis: Conceito Editorial, 2013.

SARMENTO, Daniel. Liberdade de expressão, pluralismo e o papel promocional do Estado. Revista Diálogo Jurídico, Salvador, nº 16 maio-junho-julho-agosto, 2007. Disponível em: <http://www.direitopublico.com.br>. Acesso em: 27 de fev. 2012.

SILVA, Rosane Leal da; NICHEL, Andressa; MARTINS, Anna Clara Lehmann; BORCHARDT, CarliseKolbe. Discursos de ódio em redes sociais: jurisprudência brasileira. Revista Direito GV, São Paulo, vol. 14, n. 2, p. 445-468, jul-dez 2011.

SILVA, Tomaz Tadeu da (Org.). Identidade e diferença: a perspectiva dos estudos culturais. 9. ed. Rio de Janeiro: Vozes, 2009. 
STEFFEN, César. Ódio.org.br. In: III Mostra de Pesquisa da Pós-Graduação PUCRS,2008, Porto Alegre. Programa de Pós-Graduação em Comunicação, FAMECOS PUCRS.

YOUTUBE. Haitiano Humilhado por Daniel Barbosa: Disponível em https://www.youtube.com/watch?v=WOSZu40swU8. Acesso em : 21 jun 2015.

FACEBOOK. Movimento Nacionalista Brasileiro: Disponível em: <https://www.facebook.com/permalink.php?story_fbid=966244823406058\&id=90287129974 3411>. Acesso em: 21 jun 2015.

CARTA CAPITAL. Zero Hora, vamos falar de racismo?: Disponível em: http://www.cartacapital.com.br/sociedade/zero-hora-vamos-falar-de-racismo-6431.html

\section{ANEXO}

1 - "Mais nove haitianos chegam a Porto Alegre" - Dia 31/05/2015. Disponível em: http://zh.clicrbs.com.br/rs/noticias/noticia/2015/05/mais-nove-haitianos-chegam-a-portoalegre-4771933.html

2 - "Haitianos, um racismo camuflado" - Dia 26/05/2015. Disponível em: http://zh.clicrbs.com.br/rs/noticias/noticia/2015/05/tulio-milman-haitianos-um-racismocamuflado-4768586.html

3 - "Ônibus com senegaleses e haitianos chegam a Porto Alegre" - Dia 26/05/2015. Disponível em:

http://zh.clicrbs.com.br/rs/noticias/noticia/2015/05/onibus-com-senegaleses-e-haitianoschegam-a-porto-alegre-4768548.html

4 - "Falta de coordenação dificulta acolhida de imigrantes" - Dia 26/05/2015. Disponível em: http://zh.clicrbs.com.br/rs/noticias/noticia/2015/05/falta-de-coordenacao-dificulta-acolhidade-imigrantes-4768453.html

5 - "Falta de mapeamento sobre imigrantes estrangeiros dificulta ações do Estado" - Dia 26/05/2015. Disponível em: http://zh.clicrbs.com.br/rs/noticias/noticia/2015/05/falta-demapeamento-sobre-imigrantes-estrangeiros-dificulta-acoes-do-estado-4768429.html

6 - "Õnibus chegam com 25 senegaleses e 18 haitianos a florianópolis" - Dia 25/05/2015. Disponível em: http://zh.clicrbs.com.br/rs/noticia/2015/05/onibus-chegam-com-25senegaleses-e-18-haitianos-a-florianopolis-4767831.html

7 - "Porto Alegre se prepara para receber refugiados haitianos" - Dia 24/05/2015. Disponível em: http://zh.clicrbs.com.br/rs/noticias/noticia/2015/05/porto-alegre-se-prepara-para-receberrefugiados-haitianos-4767632.html 
8 - "Imigrantes podem chegar a Porto Alegre na madrugada de domingo" - Dia 22/05/2015. Disponível em: http://zh.clicrbs.com.br/rs/noticias/noticia/2015/05/imigrantes-haitianospodem-chegar-a-porto-alegre-na-madrugada-de-domingo-4766856.html

9 - "Nenhum Ônibus com imigrantes sairá nesta quinta, afirma governo Acriano" - Dia 21/05/2015. Disponível em: http://zh.clicrbs.com.br/rs/noticias/noticia/2015/05/nenhumonibus-com-imigrantes-saira-nesta-quinta-afirma-governo-acriano-4765683.html

10 - "Governo do Acre deve enviar oito ônibus com refugiados haitianos e senegaleses para Porto Alegre". Dia 19/05/2015. Disponível em: http://zh.clicrbs.com.br/rs/noticias/noticia/2015/05/governo-do-acre-deve-enviar-oito-onibuscom-refugiados-haitianos-e-senegaleses-para-porto-alegre-4764024.html

11 - "Novos imigrantes mudam o cenário do Rio Grande do Sul" - Dia 16/08/2014. Disponível em:

http://zh.clicrbs.com.br/rs/noticias/noticia/2014/08/novos-imigrantes-mudam-o-cenario-dorio-grande-do-sul-4576728.html 